\title{
C-15 STRATIGRAPHIC ARCHITEGTURE OF THE TRIASSIC RESERVOIR IN THE SAHARAN PROVINCE, ALGERIA
}

G. DESAUBLIAUX' R. ESCHARD', D. BEKKOUCHE ${ }^{2}$ and A. HAMEL ${ }^{2}$

Institut Français du Pétrole, 1 \& 4 Avenue Bois Préau, 92582 Rueil Malmaison, France

\begin{abstract}
The Triassic reservoir is one of the most prolific plays in Algeria since the beginning of the exploration. One of the exploration risk is linked to the distribution and heterogeneity of the reservoir: Triassic series were mostly deposited in continental to lagoonal depositional environments, and reservoirs mostly correspond to channelised fluvial sandstones interfingering with floodplain and sabbkha sediments.

A project was then designed to established the stratigraphic architecture of these series at a regional scale, using outcrop data in Algeria and Tunisia, 125 wells with a very good core recovery, and palynological analysis. A new interpretation of the tectono - sedimentary evolution of the basins is then proposed. Eight depositional sequences were determined and correlated all across the area, and detailed sedimentological interpretation of their internal architecture was made possible with the outcrop and core studies.

Upper Triassic series were onlapping Paleozoic sediments folded during the Hercynian orogen. During upper Ladinian times, the whole area was eroded and incised valley systems were probably guided by the Hercynian unconformity morphology. Triassic sediments were only deposited in the northern part of the Sahara and in southern Tunisia, along the Paleo - Thethys margin.

During Carnian times, a rifting phase induced the reactivation of old Panafrican lineaments, and large North - South horsts and grabens were formed. Two main basins, the Illizi - Berkine basin and the Oued Mya basin were separated by the El Biod - Hassi Messaoud high, and bounded eastwards and westwards by uplifted areas. These highs were associated to normal syn - sedimentary faults, inducing important thickness and facies variations; and an active volcanism. In the Illizi basin, alluvial fans supplied sediments eroded from the highs to the graben axis, where extended floodplain and ephemeral lake sediments. Carbonated sediments, associated to transgressive events linked to the Paleo - Thethys opening, were interfingered in these alluvial sediments. The Oued Mya basin was covered at the same time by a wide sandy braided - plain.

During Norian times, fault activity decreased, and a post - rift thermal subsidence affected the whole province. The whole fluvial system backstepped through time, and horsts were progressively onlapped and covered by alluvial sediments. A wide sabbkha, connected to the Paleo - Thethys, extended in the North of the Illizi - Berkine basin, in which coarse - grained fan - deltas interfingered with the evaporites. Alluvial plain sediments covered the Oued Mya area. Triassic sedimentation ended with a regional transgressive event depositing a thin dolomite bed, overlaid by a thick series of Liassic evaporites.
\end{abstract}


One of the main result of this study is then to show the diachronism of the Triassic series associated to the backstep of the fluvial sediments as the subsidence pattern of the basins evolved through time.

The TAGI reservoir succession in block 208 comprises fluvial and lacustrine sediments deposited on the regionally extensive Hercynian uncomformity. The fluvial system is sand rich, with sand-shale ratios commonly in the 60 to $80 \%$ ranges. Deposition of reservoir sands occurred predominantly in extensive braided river tracts. Extensive reworking of the braided river sands combined with mature mineralogy and limited post depositional diagenetic degradation has resulted in well sorted, highly permeable and porous reservoirs. Correlation of lacustrine mudstone intervals indicates that the braided sand bodies are laterally extensive. Reservoir continuity on the order of kilometers is demonstrated by pressure transient analysis of well tests.

The main trapping mechanism in block 208 is structural, with individual fields typically comprising very low relief structures bounded by large NE_SW trending master faults, with throws up to $\sim 200$ meters. Smaller antithetic faults of variable throw magnitude, ranging from $<10$ meters to a few tens of meters, subdivide fields into a serie of tilted fault blocks. Antithetic faulting has had a significant impact on reservoir structure and fluid distribution. Fault movements subsequent to hydrocarbon migration and accumulation have resulted in differences in elevation of hydrocarbon-water contacts across faults, which are in the order of a few meters. These elevation differences are related to fault throws and complex spatial variations in fault sealing capacities.

The geographical and subsurface depth distribution of field s dictates that an integrated project development, encompassing the EMK, EME, EMN, and EKT fields, is the optimal development plan. To refine field development planning, extensive 3D seismic surveys $\left(>650 \mathrm{~km}^{2}\right)$ have been acquired over the EKT, EMN and EMK fields. Ongoing and future delineation activities will focus on reducing the remaining subsurface uncertainties prior to field development. 




$$
4
$$

